\title{
TAKING SCRIPTURE SERIOUSLY: LEIBNIZ AND THE JEHOSHAPHAT PROBLEM
}

\section{LEIBNIZ’S COMMITMENT TO CHRISTIANITY}

Leibniz's commitment to Christianity has been questioned for centuries. In his own day he was referred to by Hanoverian wags as 'glaubenichts' (one who believes in nothing) on the grounds that he rarely attended Church or took communion. ${ }^{1}$ More recently, Stuart Brown has claimed that Leibniz 'shows a tendency to deism', ${ }^{2}$ while George MacDonald Ross has argued that Leibniz was 'essentially a pagan metaphysician'. ${ }^{3}$ Both Brown and Ross provide solid grounds for their respective assessments; in Brown's case, that Leibniz's thought leaves no room for either miracles or providence as they have been traditionally conceived by Christians, ${ }^{4}$ and in Ross' case that Leibniz endorses accounts of creation which bear little relation to and in fact may be inconsistent with - the Biblical account. It seems undeniable that on certain issues in which his philosophy led him to a position at odds with orthodox Christian thinking, Leibniz had a pronounced tendency to subordinate his theology to his philosophy, with the result that he marginalised certain doctrines one would typically expect a committed $17^{\text {th }} / 18^{\text {th }}$-century Christian to hold. This is true not just of creation, miracles and providence, but also of (to take two further examples) prophecy and the age of the world. With regard to prophecy, Leibniz favoured naturalistic explanations, being loathe to admit the supernatural in any event bar that of creation..$^{5}$ And as for chronology, Leibniz's geological studies led him to suppose that the earth - and hence the world - was considerably older than the 6000-years suggested by a literal reading of the Bible. ${ }^{6}$

Yet painting Leibniz as little more than a nominal Christian is not straightforward. For one thing, Leibniz expended a great deal of effort to show the reasonableness of belief in Christian doctrines such as the Resurrection, the Trinity, the Incarnation, and the Eucharist. ${ }^{7}$ For another, references (and deferences) to scripture abound in Leibniz's writings; they are not just scattered throughout his ecumenical works, where one might reasonably expect to find them, but also throughout many of his most wellknown writings such as the Philosopher's Confession, the Discourse on Metaphysics, the Theodicy, as well as his correspondence. ${ }^{8}$

It is, however, possible to explain away both of these features of Leibniz's work. In the first case, a great many of Leibniz's writings in defence of various Christian doctrines were part of his youthful Catholic Demonstrations project, instigated in the late 1660s at the request of his (Catholic) employer in Mainz, Johann Christian von Boineburg, and resurrected in the 1680s. This project was closely allied to the church reunion efforts Leibniz eventually became involved with, and these of course had wider political ramifications. ${ }^{9}$ The motivation behind Leibniz's defence of core Christian doctrines may therefore have been political; Leibniz was, after all, a diplomat by profession, and knew what was required to achieve the desirable goal of religious harmony. Any suspicion that Leibniz may not have been personally committed to the philosophy he developed in his defence of various Christian doctrines is reinforced when, in a paper defending the doctrine of the resurrection of the same body, he candidly states half-way through that grounds for the doctrine itself are lacking, before proceeding to offer a clever philosophical account of how all can be resurrected with the same body anyway. ${ }^{10}$ And in another text written shortly afterwards, he asserts that there is no need to insist on humans being resurrected with the same body at all. ${ }^{11}$ As for Leibniz's use of scripture in his philosophical work, it 
must be remembered that in an age which frowned on novelty and unorthodoxy, it was commonplace for philosophers to show that their ideas harmonized with the Bible, or at least were not in conflict with it. A liberal scattering of choice scriptural passages in one's work was the accepted method to show that this was indeed so. ${ }^{12}$ So it is possible to explain away Leibniz's apparent commitment to Christianity, as revealed in his defences of specifically Christian doctrines and by his frequent references (and deferences) to scripture in his philosophical work, to leave us with a figure resembling Brown's deist or Ross' pagan metaphysician.

\section{THE JEHOSHAPHAT PROBLEM}

Yet there are other Christianized features of Leibniz's work which are not so easy to explain away. One such is his decision to advance a solution to the problem of whether (or how) all the humans who had ever lived can simultaneously fit into the valley of Jehoshaphat. As will become clear, this is not a problem that would trouble either a pagan metaphysician or someone inclined towards deism.

Although this problem may strike modern minds as little more than a pleasant diversion, akin to a trivia question, it was not considered so in medieval and early modern times. The problem itself was bound up with the widely accepted Christian belief that the valley of Jehoshaphat was to be the scene of the last judgement, and so the place where all the resurrected would, at some future time, be gathered together. The sources of this belief are two verses in the Old Testament Book of Joel:

I will gather together all nations, and will bring them down into the valley of Jehoshaphat... (Joel 3.2)

Let the nations be roused; let them advance into the Valley of Jehoshaphat, for there I will sit to judge all the nations on every side. (Joel 3.12)

Although scripture contains no further references to the valley of Jehoshaphat, on the basis of the two passages cited above there developed a tradition which identified this valley as the location of the last judgement. Moreover, in the first millennium of the common era it became an accepted part of this tradition that the valley in question was in fact the one which lies east of Jerusalem, between the city and the Mount of Olives, and through which the brook Kidron runs following the rains in the winter months (the valley today known variously as the Kidron, Cedron, or Qidron valley). ${ }^{13}$ A glance at a map confirms the assessment of one $19^{\text {th }}$-century writer that this valley is 'comparatively as big as the palm of your hand',${ }^{14}$ although the valley between Jerusalem and the Mount of Olives runs for many miles, all the way to the Dead Sea around twenty miles away, historically only the portion separating Jerusalem and the Mount of Olives has been recognized as the valley of Jehoshaphat. Moreover, this small portion, while steep, is very narrow, at less than a mile wide. Its length is scarcely any greater. It thus takes no great effort of imagination to spot a degree of tension between the relatively small area afforded by this valley and the belief that it has been chosen as the site of the last judgement, which involves the gathering together of all the humans who have ever lived. The tension created by the size of the valley on the one hand, and its identification as the future site of the last judgement on the other, gave rise to what I shall henceforth call 'the Jehoshaphat problem'. ${ }^{15}$ The history of this problem (and the solutions it elicited) has yet to be written; the problem goes back at least as far as Aquinas, ${ }^{16}$ and was still being discussed deep into the $18^{\text {th }}$. 
century, ${ }^{17}$ and along the way attracted the attention of thinkers as diverse as Jacobus de Voragine (c.1229-98), ${ }^{18}$ Jan Ruysbroeck (1293-1381), ${ }^{19}$ and Cornelius a Lapide $(1567-1637) .^{20}$

As should be clear from its origins, the Jehoshaphat problem would only be of concern to someone who takes both scripture and Christian tradition seriously, or rather, to someone who is committed to their truth. It is therefore noteworthy, given the evidence for his being little more than a nominal Christian, that Leibniz seemingly was concerned with the Jehoshaphat problem. That Leibniz took the problem seriously at all is especially remarkable given that many of his contemporaries preferred to dissolve it through hermeneutical means. ${ }^{21}$ The Lutheran theologian Johann Ernst Gerhard (1621-68), for instance, claimed that in the phrase 'the valley of Jehoshaphat' found in the book of Joel, 'Jehoshaphat' served 'not as a proper name...but as an appellative name. For "Jehoshaphat" is the same as "the judgement of the Lord". ${ }^{22}$ He was by no means the first to realize this - in a $4^{\text {th }}$ century letter, St. Jerome noted that, in Hebrew, 'Jehoshaphat' "means "the judgement of the Lord", 23 While Jerome didn't draw any firm conclusions about the location of the last judgement on the basis of this etymology, Gerhard did. He claimed that since 'Jehoshaphat' means 'the judgement of the Lord', then 'By "the valley of Jehoshaphat" he [the author of Joel] means the place the Lord shall choose for judgement, wherever it shall be. ${ }^{24}$ So in Gerhard's view, when the author of Joel referred to the valley of Jehoshaphat he wasn't referring to any specific geographical location like the valley between Jerusalem and the Mount of Olives, but rather somewhere indeterminate. Other writers made precisely the same assertion: ${ }^{25}$ Edward Pococke (1604-1691) claimed on the basis of the etymology of the word 'Jehoshaphat' that the valley of Jehoshaphat mentioned in Joel as the scene of the last judgement was 'any such place, wherever it should be, where God should in such manner...execute judgement' ${ }^{26}$ John Calvin had come to the same conclusion in the $16^{\text {th }}$ century, albeit with a measure of hesitancy, ${ }^{27}$ while in the $17^{\text {th }}$ - and $18^{\text {th }}$-centuries the conclusion was confidently reached by numerous thinkers, including Bénédict Pictet (1655-1724) ${ }^{28}$ and Peter Dens (1690-1755). ${ }^{29}$ Given Leibniz's great interest in the Hebrew language, etymologies, and scriptural exegesis and hermeneutics, and his penchant for employing hermeneutical devices such as accommodation, allegorical interpretations and so on, ${ }^{30}$ one might have expected him to have fallen in with the fashionable exegetical manoeuvre endorsed by Gerhard, Pococke et al, and therefore not troubled himself with devising a solution to the Jehoshaphat problem. But he did not take this route. Yet there is little doubt that Leibniz was aware of the etymology of the word 'Jehoshaphat', it being noted, for instance, in Cardinal Bellarmine's De arte bene moriendi, which Leibniz cited in several of his own writings. ${ }^{31}$ Moreover, it is also likely that he was aware that this etymology had been used as a basis to deny that the last judgement would be held in the valley traditionally identified as the valley of Jehoshaphat, as he owned and regularly quoted from an edition of the works of Calvin, and was very well read in other works of contemporary theology. It is therefore noteworthy that while others of his age sought to resolve the Jehoshaphat problem by hermeneutical means, Leibniz opted to take it at face value and show precisely how all of the resurrected could simultaneously fit in the valley.

Leibniz treated the Jehoshaphat problem on two separate occasions, both late in his career, in 1711 and 1715. In sections III and IV I shall examine these two treatments in turn, while in section V I shall consider what conclusions should be drawn from them with regard to the rival explanations of Leibniz's theology outlined earlier, namely the 'deist/pagan' interpretation and the 'committed Christian' interpretation. 


\section{LEIBNIZ'S FIRST TREATMENT}

Leibniz's first solution to the Jehoshaphat problem is to be found in a letter to his patroness, Electress Sophie of Hanover, from 26 June 1711. Leibniz's remarks are made in response to an undated letter from Bernard le Bovier de Fontenelle, secretary of the French Royal Society and sometime journal editor, to the Marquis de la Fare. ${ }^{32}$ (This letter took a very circuitous route to reach Leibniz's hands: its recipient was captain of the guards under Philippe II, the Duke of Orléans, who passed a copy of it to his mother, Duchess Elisabeth Charlotte of Orléans, who sent it to her aunt, Electress Sophie, who in turn passed it to Leibniz.) In this letter, Fontenelle treated in a very lighthearted manner - the question of whether all the humans who have ever lived could simultaneously fit on the entire surface of the Earth, as would have to happen at the time of the resurrection. ${ }^{33}$ The following is Leibniz's response:

This question has already been discussed by philosophers and by theologians. One finds, with the aid of geometry, that all the men taken together over some thousands of years...could easily be accommodated on a rather small part of the surface of our globe: and a certain author even attempted to determine by this calculation how long our world could last at the very most. ${ }^{34}$ For as all the men since Adam up to us must be found room on the day of judgement in the valley of Jehoshaphat, human kind will not undergo any further increase in numbers once there are enough men to fill this Palestinian valley. So there is no need to subtract anything from the flesh and bones of men in order to find room for them. And if it were even possible that each person should keep all the matter he has possessed since his birth, and that on the day of judgement he should be as big as a tower, there would be a way of finding room for all. When people are a little too crowded around a table, all they have to do to have more elbow room is everywhere move away from it a little, from the centre towards the circumference, and so it is here: the good Lord would only have to pull men a little into the air to meet with him, and in this way there would be room for them, even if there were a lot more of them. ${ }^{35}$

Leibniz offers two solutions to the Jehoshaphat problem here. The first, which is the one he endorses, is that all will be able to fit in the valley. Leibniz's allusion to a geometrical proof of this is unfortunately not accompanied with any indication of where it might be found; at any rate such proofs were not uncommon in the early modern period, as we shall see in section IV. (His claim that there will be no need to subtract anything from the bodies of the resurrected is made in response to a suggestion in Fontenelle's letter that certain portly people, like the recipient of his letter, the Marquis de la Fare, will be resurrected in much slimmer bodies than they possess in this life.)

Leibniz's second solution, that men will be raised in the air over the valley, applies only in the event that humans are resurrected as giants, that is, with bodies containing all of the matter which formed part of their bodies at some time during normal life. It is unclear why Leibniz should consider this possibility; it is not based on anything in Fontenelle's letter to de la Fare, nor was it in any way a mainstream position at the time, or one which could boast of any meaningful support. The only explanations I can muster for Leibniz's taking it into consideration are either that he was responding to something contained in a no longer extant letter from either Sophie or Elisabeth 
Charlotte, or that he was simply being thorough, showing that the Jehoshaphat problem admitted of a solution even in the extreme case of humans being resurrected as giants. In suggesting that men could be raised in the air over the valley of Jehoshaphat, it is tempting to suppose that Leibniz had in mind a passage from 1 Thessalonians 4.16-17, where it says, with reference to the day of judgement:

For the Lord himself shall descend from heaven with a shout, with the voice of the archangel, and with the trump of God: and the dead in Christ shall rise first: Then we which are alive and remain shall be caught up together with them in the clouds, to meet the Lord in the air: and so shall we ever be with the Lord.

I think it unlikely, however, that Leibniz had this passage in mind when suggesting that men may be pulled into the air over the valley. First, he makes no mention of it, yet more often than not he makes it clear when he is quoting or paraphrasing scripture. Second, the passage from 1 Thessalonians refers to the blessed and those who are still alive at the time of the resurrection being raised into the clouds, whereas the most natural reading of Leibniz's remarks is that all will be so raised. ${ }^{36}$

In framing this solution, I suggest that Leibniz approached the Jehoshaphat problem as a simple mathematical puzzle, and solved it by applying a simple mathematical principle (if it turns out that more room is required, move away from the centre towards the circumference). The solution, while ingenious in many ways, does have the drawback of deviating from a literal interpretation of Joel 3.2 and 3.12, both of which state that people are brought into the valley of Jehoshaphat (not over, above, or in the airspace over). This would seem to suggest a gathering on the valley floor, though there were certainly precedents for supposing that at least some of the resurrected would be situated in the air over the valley. Peter Lombard (1095-1160), for instance, stated that only those to be damned would be in the valley itself, whereas ' $[\mathrm{t}]$ he just...will not descend into the valley of judgement, that is, into damnation; instead they will be raised into the clouds to meet with Christ. ${ }^{37}$ Leibniz of course goes further, and envisages everyone being in the clouds, or at least in the air, which suggests a twofold interpretation of the key passages from Joel: first, literalism as to the geographical location of the last judgement, and secondly, non-literalism as to whereabouts people will be situated in relation to the valley itself. Underwriting the second, non-literal interpretation is of course the belief that the valley is insufficiently spacious to accommodate all of the resurrected at once, and as we have seen, this was not a belief Leibniz held.

\section{LEIBNIZ'S SECOND TREATMENT}

Leibniz's second treatment of the Jehoshaphat problem, found in a short untitled draft note written around $1715,{ }^{38}$ can be seen as a development of the first. While he remains of the view that the valley of Jehoshaphat is ample enough to contain all, in the 1715 note he attempts to demonstrate this belief via mathematical calculation. As this note is still unpublished, it is worth quoting here in full:

Let us suppose that on the earth now there are one hundred million souls, and that the men are replaced every 50 years. If we grant that the world has existed for 6000 years, in accordance with the usual chronology, there will be 120 renewals. But as the number of men was smaller in the beginning, let us content 
ourselves with 100 renewals of 100 million men, so all the men together would make ten thousand million.

Now a German league being 4000 paces and a pace being 5 feet, it will be 20000 feet, and such a league squared will be 400000000 square feet, that is, four hundred million square feet. Let us grant a square foot to each man, for although a man can be wider, as a rule he is smaller. So if the valley of Jehoshaphat were taken in such a way that it included the whole course of the stream which makes the region around Jerusalem fertile, and around a length of $12 \frac{1}{2}$ leagues with a width of 2 leagues, on average, this valley would contain 25 square leagues, and consequently ten thousand million square feet, without counting the fact that there is an enormous number of small children who will have no need at all for so much space. ${ }^{39}$

This unpolished text, clearly one of Leibniz's numerous 'memoranda for self', offers a fascinating insight into many areas of Leibniz's thought, and as such will repay careful examination.

Although Leibniz here succeeds in showing to his own satisfaction that the valley of Jehoshaphat affords sufficient space for all, his estimates and calculations deserve some comment. First, in terms of the number to be accommodated, Leibniz's figure of $10,000,000,000$, is remarkably low even in comparison with the estimates of other early modern thinkers who also assumed a six thousand-year chronology. ${ }^{40}$ Second, Leibniz's relatively low estimate for the number of humans to be accommodated inevitably leads to a relatively low estimate of the amount of space required for them, though because of the uncertainty about the size of the units of old measurements, especially of old German measurements which varied from state to state, it is not easy to determine just how large Leibniz took this space to be. To illustrate, scholars have variously defined the old German league or mile as being 4.4 present miles, ${ }^{41}$ approximately 4.6 present miles, ${ }^{42}$ and 5 present miles ${ }^{43}$ (there are also various other estimates which fall outside of this range), so quite possibly Leibniz's position is that 10,000,000,000 humans will require an area of between approximately 110 and 125 present square miles. By a happy calculation, Leibniz determines that the space available in the valley of Jehoshaphat is sufficient to accommodate all, though such a neat result is bought at the price of grossly overestimating the size of the valley of Jehoshaphat. It seems Leibniz was aware of this, given his remark that 'if the valley of Jehoshaphat were taken in such a way that it included...', which is an acknowledgement that for the purposes of the issue at hand he is construing the valley of Jehoshaphat to include some of the area beyond it - in fact, given his measurements, he is probably construing it as including the remainder of the valley through which the Kidron brook runs, all the way to the Dead Sea. One can only assume that Leibniz did not have an accurate map at his disposal, because even if it is legitimate to construe the valley of Jehoshaphat as extending all the way to the Dead Sea, his calculation that the valley has an area of twenty five square leagues (approximately 110-125 present square miles) is generous to the point of being a gross exaggeration. In spite of its shortcomings, Leibniz's response to the Jehoshaphat problem is nothing less than an attempt to demonstrate mathematically that the valley of Jehoshaphat is large enough to accommodate all. As such, it is part of a pattern of early modern responses to the Jehoshaphat problem which attempt to resolve the problem via simple mathematical calculation. For example, Marin Mersenne (15881648), always keen to show the practical value of mathematics, calculated that all the 
humans who had ever lived could be accommodated together in and around the valley of Jehoshaphat:

the globe of the earth and the water are large enough to carry $148,456,800,000,000$ men, provided that each occupies only a square foot. Now according to these hypotheses, all the blessed and all the reprobate could be contained in the 40th part of terra firma, if we give a square foot to each; consequently the valley of Jehoshaphat, with the neighbouring places up to 8 degrees all around, could contain all those who will be present on the day of the last judgement. ${ }^{44}$

The Jesuit François-Xavier de Feller (1735-1802) came to a very similar conclusion via a similarly speculative mathematical route. He calculated that the number of people who had ever lived was $200,000,000,000$, each of whom will require one square foot of space apiece at the time of the last judgement. Although this is considerably more space than the area afforded by the valley of Jehoshaphat, Feller refuses to consider this a problem, on the grounds that 'It has never been thought that the valley of Jehoshaphat had to contain all the men who returned at the universal judgement, but rather that this valley would form the centre of this vast assembly. ${ }^{, 45}$ Feller thus states explicitly what Mersenne only implied, namely that at the last judgement it is sufficient for people to gather in and around the valley of Jehoshaphat. Leibniz's suggestion in his 1715 text on the Jehoshaphat problem is cut from the same cloth: like Mersenne and Feller, Leibniz finds that the figures do not permit the accommodation of all within the area traditionally identified as the valley of Jehoshaphat, and consequently he treats some of the area around the valley as the overspill which will accommodate those who cannot fit into the valley itself. The chief difference between Leibniz's solution and that offered by Mersenne and Feller is that the latter pair treat the valley of Jehoshaphat as the centre point of this vast assembly, while Leibniz does not, preferring instead to have the surplus gather in the parts of the valley not traditionally considered to be the valley of Jehoshaphat.

From the fact that Leibniz returned to the Jehoshaphat problem and sought to provide a mathematical basis for his earlier claim that the valley was spacious enough for all, we can infer that he took the Jehoshaphat problem very seriously, more seriously than one might perhaps have expected given his portrayal as a pagan metaphysician, or someone with leanings towards deism.

\section{LEIBNIZ'S TREATMENTS IN CONTEXT}

It is therefore tempting to conclude that Leibniz's decision to apply himself to the Jehoshaphat problem shows that he was in fact a committed Christian, personally concerned with problems arising out of scripture and Christian tradition. After all, the circumstances surrounding the composition of his treatments of the Jehoshaphat problem do not themselves offer any basis for doubting the sincerity of those treatments. In the case of the letter to Electress Sophie, Leibniz was responding to a problem raised by Fontenelle, that of whether the Earth will have sufficient room for all after the resurrection. Fontenelle made no mention of the valley of Jehoshaphat, nor is there any evidence that Leibniz was pressed to refer to it and/or the associated Jehoshaphat problem at someone else's behest. Consequently, Leibniz's decision to respond to Fontenelle's letter by focusing on the Jehoshaphat problem was his own. As such, we may say that Leibniz was internally motivated to introduce and discuss 
the Jehoshaphat problem, rather than externally motivated. As for the 1715 text on the Jehoshaphat problem, this too seems to have been internally motivated; at any rate Leibniz certainly does not mention any external factors which led him to compose it: he simply sets out to solve the Jehoshaphat problem. The date of composition supports this reading: in 1715 Leibniz was no longer involved in any ecumenical projects and therefore was not writing texts in support of such ventures. The Catholic Demonstrations project, along with his other irenical efforts, were at that time long since abandoned. By all accounts, the 1715 text is as it appears to be - a short memorandum for self, motivated purely by personal interest or concern. ${ }^{46}$

Yet with Leibniz very little is ever straightforward, and there are elements of the second of his two treatments of the Jehoshaphat problem which make it difficult to state unequivocally that it ought to be interpreted as solid evidence of a personal commitment to Christianity. The two I shall focus on are chronology and the resurrection.

In the 1715 text, Leibniz considers the Earth to be 6000 years old, which would date creation to around 4000BC or thereabouts. That Leibniz would accept such a chronology would perhaps be unsurprising but for the fact that, from 1687 onwards, he identifies a need to endorse a chronology based on the Septuagint, which dates creation at around 5200BC. ${ }^{47}$ Like other thinkers of his time, his reason for inclining towards the Septuagint was that it enabled the Biblical account of history to be reconciled with Chinese history, which by all accounts required more time than a Vulgate-based chronology was able to offer. ${ }^{48}$ Yet the 1715 text on the Jehoshaphat problem suggests that Leibniz ultimately abandoned his previously-stated inclination for the Septuagint chronology in favour of one based on the Vulgate, as in it he assumes the latter rather than the former. If this assumption does indicate a genuine change of heart over which chronology to favour, then how is it to be explained? One possibility is expediency - a Vulgate-based chronology would permit a lower estimate of the number of people who have ever lived, which in turn would make the Jehoshaphat problem easier to solve. Another possibility is that Leibniz was not sincere when he expressed a preference for the Septuagint-based chronology; after all, this preference is to be found only in letters to people who Leibniz knew were also concerned with harmonizing Biblical and Chinese history, and as such his stated preference for the Septuagint may have been due to his desire to appear 'orthodox' on this issue (that is, to be seen as following the dominant trend of the time). I can see no way of adjudicating between these possibilities. It is quite likely, however, that neither of them is correct. I mentioned in section I that Leibniz's geological studies led him to suppose that the earth is much older than is suggested by a literal reading of the Bible, and that remains true whether the Bible is understood as the Vulgate or the Septuagint. Leibniz apparently never abandoned his views on the formation of the earth and its early (pre-human) history, repeating them in texts as late as 1710 and $1714,{ }^{49}$ which suggests that he never abandoned his belief that the earth is older than a literal reading of the Bible would intimate. If so, then ultimately Leibniz accepted neither a Vulgate- or Septuagint-based chronology.

It might be thought possible to square Leibniz's geological commitments with his apparent acceptance of one or other of the biblical chronologies by drawing a careful distinction between the age of the earth on one hand, and the age of humanity on the other. So it might be argued that while Leibniz believed that the earth itself had existed for much more than six millennia, he also held that human history only dated back around 6000 years (and presumably was as indicated in one interpretation of scripture or another). If Leibniz did indeed draw this distinction, then it was done so 
only in his own mind: there are no texts in which he addresses this matter explicitly. However there is at least one text in which Leibniz clearly leaves no room for the aforementioned distinction, namely the 1715 text on the Jehoshaphat problem. In this text, as we have seen, he writes 'If we grant that the world has existed for 6000 years...'. Here Leibniz is giving a date for the creation of the world, and he goes on to assume that it also marks the beginning of human history.

This generates something of a headache for Leibniz scholars, as Leibniz appears to accept three mutually incompatible chronologies, one based on his geological studies, one based on the Septuagint, and, in the 1715 text on the Jehoshaphat problem, one based on the Vulgate. Which of these got his earnest support is difficult to determine, though I suspect he favoured the first of the three simply because it is a corollary of his own research. If that is correct, then Leibniz accepted neither the Vulgate- or Septuagint-based chronologies, which in turn casts doubt as to the sincerity of his second treatment of the Jehoshaphat problem.

The 1715 text throws up another puzzle for Leibniz scholars, in the form of the rare insight it throws into Leibniz's eschatology. Leibniz often stated that scripture had not provided much detail about what happens after this life, ${ }^{50}$ and he was critical of others who confidently provided such details (e.g. Francis Mercury van Helmont). ${ }^{51}$ Yet in the 1715 text, Leibniz seems to adopt a very specific (and very unusual) position regarding the resurrection of those who die as children. Consider his remark at the end of the text, that 'small children...will have no need at all for so much space'. The most obvious interpretation has Leibniz saying that small children will have no need for a square foot of space apiece in the valley of Jehoshaphat, which strongly suggests that Leibniz held that those who die as children will be resurrected as children, or at least with child-sized bodies. One might reasonably suppose that if Leibniz did endorse this view he would have mentioned it in other writings. But he didn't. Nor was it a view that was so in tune with orthodoxy that one's adherence to it required neither statement nor justification. Far from it in fact: such a view was out of step with traditional Christian thinking of the time, which held that everyone will be resurrected as mature adults, even those who died as children. Augustine, for instance, claimed that children 'will not have, in the resurrection, the tiny bodies in which they died', but rather 'by God's wonderful and immediate action' they will be resurrected with bodies 'the size they would have reached in time by the slow process of growth'. ${ }^{52}$ Aquinas, meanwhile, held that 'all must rise in the age of Christ', which implies that all will be resurrected with bodies of 30 -year old adults. ${ }^{53}$ Scriptural grounds were often cited in support of this view, for instance Ephesians 4.13: 'until we all ... become mature, attaining to the whole measure of the fullness of Christ'. Leibniz was well aware both that this view had the support of thinkers such as Augustine and that there was an apparent scriptural basis for it, mentioning both in a short paper on the resurrection. ${ }^{54}$ Another reason for following the position outlined by Augustine and Aquinas was the apparent difficulty with the alternative, for if those who died as children are resurrected as children, then consistency would seem to require that those who died as foetuses are resurrected as foetuses. Such a thought was often considered to serve as a reductio of the claim that humans are resurrected with numerically the same bodies they had at the point of death, for instance by John Locke. ${ }^{55}$ In apparently rejecting this view, Leibniz may well have bought himself extra space in the valley of Jehoshaphat, but at the cost of adopting a position at sharp odds with traditional Christian thinking, as he knew, and which was associated with thorny problems of its own, which he also knew, having read Locke's attack on it. ${ }^{56}$ 


\section{CONCLUSION}

Ultimately, then, Leibniz's treatments of the Jehoshaphat problem can be construed as evidence both for and against the 'deist/pagan' interpretation and the 'committed Christian' interpretation. On the one hand, the fact that Leibniz wished to solve the problem at all, for his own reasons, suggests a strong commitment to Christianity, since no deist or pagan would feel the need to take the problem seriously. On the other hand, certain elements of Leibniz's second solution, from 1715, are such as to raise doubts about whether he was sincere in advancing it. His apparent allegiance to a Vulgate-based chronology in the 1715 text is flatly contradicted by an avowed leaning towards a Septuagint-based chronology elsewhere, and both are undercut by the results of Leibniz's geological work. Moreover, his insinuation in the same text that those who die as children will be resurrected as children is a thought not to be found elsewhere in his corpus; yet the fact that it is at odds with traditional Christian thinking and problematic in its own right (as he well knew), means that one would expect Leibniz to have tried to justify it (to himself at least) if indeed it was a view he sincerely held.

Leibniz was undoubtedly a complicated man, and his true religious beliefs and commitments are hard to tease out from the enormous range of writings he left behind, some of which can support radically disparate interpretations, as we have seen. Richard Popkin once asked: 'Do we have to have two, or maybe three, or four Leibnizes to make him compatible...?' ${ }^{57}$ Although one should not multiply Leibnizes without necessity, it is clear that the complexity of the man's beliefs (and perhaps the tension between them, if ultimately there be such) will require much greater efforts from scholars to weave into a single, consistent picture than has heretofore been applied.

\section{Notes}

My thanks to Daniel J. Cook, Tom O’ Loughlin, and Vernon Pratt for their helpful comments on an earlier draft of this paper.

\footnotetext{
${ }^{1}$ See, for example, Duchess Elisabeth Charlotte of Orléans' letter to Electress Sophie of 22 October 1711 in Eduard Bodemann (ed.), Aus den Briefen der Herzogin Elisabeth Charlotte von Orléans an die Sophie Kurfürstin von Hannover (Hanover: Hahn, 1891), II, p. 292.

${ }^{2}$ Stuart Brown, 'The regularization of providence in post-Cartesian philosophy', in Robert Crocker (ed.), Religion, Reason and Nature in Early Modern Europe (Dordrecht: Kluwer, 2001), p. 3.

${ }^{3}$ George MacDonald Ross, 'Leibniz and the origin of things', in Marcelo Dascal and Elhanan Yakira (eds.), Leibniz and Adam (Tel Aviv: University Publishing Projects Ltd, 1993), p. 252.

${ }^{4}$ Brown, 'The regularization of providence', pp. 10-13.

${ }^{5}$ See Daniel J. Cook, 'Leibniz and the Problem of Miracles', Religious Studies 45 (2009), forthcoming.

6 'Leibniz did not calculate the timescale implied by his history [of the earth], though he did recognize that if fossil shells were the true remains of animals, the earth itself must have been much older than the Bible claimed.' Claudine Cohen and Andre Wakefield, 'Introduction', in G. W. Leibniz, Protogaea, trans. and ed. Claudine Cohen and Andre Wakefield (Chicago: University of Chicago Press, 2008), p. xxviii.

${ }^{7}$ This is the central thread of Maria Rosa Antognazza's book, Leibniz on the Trinity and the Incarnation (London: Yale University Press, 2007).

${ }^{8}$ This has gone unnoticed by some scholars. Matthew Stewart, for example, writes 'It is a fact worthy of notice that, although he lived in a century noted for its Bible thumping, Leibniz rarely bothered to cite the scriptures in his philosophical works.' Matthew Stewart, The Courtier and the Heretic (New York: W. W. Norton, 2006), p. 114.
} 
${ }^{9}$ Ursula Goldenbaum notes that Leibniz became acutely aware early in his career that the mysteries, i.e. the doctrines of the Trinity, Eucharist, and the Incarnation, 'make up the very essence of Christianity', and 'to give them up would destroy the Christian religion'. Ursula Goldenbaum, 'Spinoza's parrot, Socinian syllogisms, and Leibniz's metaphysics: Leibniz's three strategies of defending Christian mysteries', American Catholic Philosophical Quarterly 76 (2002), pp. 556-7. Leibniz noted often enough the unwelcome political and social consequences of the schism, and no doubt feared even worse consequences should the Christian religion suffer further fractures or even collapse. Therefore Leibniz may well have had prudential reasons for defending the mysteries and other doctrines seen as integral to Christianity. See Catherine Wilson, Leibniz's Metaphysics (Manchester: Manchester University Press, 1989), pp. 299f.

${ }^{10}$ See G. W. Leibniz, Sämtliche schriften und briefe, ed. Akademie der Wissenschaften, multiple volumes in 7 series (Berlin: Akademie Verlag, 1923-), series II vol. 1 ( $2^{\text {nd }}$ edn.), p. 184. Hereafter: A, series no., vol. no. For more information on Leibniz and the resurrection, see Lloyd Strickland, 'The doctrine of "the resurrection of the same body" in early modern thought', Religious Studies 45 (2009), forthcoming, and Lloyd Strickland, 'Leibniz, the flower of substance, and the resurrection of the same body', The Philosophical Forum 40 (2009), forthcoming. Catherine Wilson notes that Leibniz's attitude to the doctrine of transubstantiation was likewise one of 'external, intellectual interest. He would like to give satisfaction to those who do accept the dogma, but he does not accept it himself.' Wilson, Leibniz's Metaphysics, p. 301.

${ }^{11}$ A VI 3, 479. English translation in G. W. Leibniz, De Summa Rerum, trans. and ed. G. H. R. Parkinson (New Haven: Yale University Press, 1992), p. 35.

${ }^{12}$ No doubt there are other explanations for some of Leibniz's numerous references to scripture in his work. For instance, Patrick Riley suggests that in one text, the 'Mars Christianissimus', Leibniz's 'constant citation of scripture is probably intended as a parody of Bossuet's style'. G. W. Leibniz, Political Writings, trans. and ed. Patrick Riley (Cambridge: Cambridge University Press, 1988, $2^{\text {nd }}$ edn.), p. 121.

${ }^{13}$ For details of how this tradition developed, see Thomas N. Hall, 'Medieval traditions about the site of judgment', Essays in Medieval Studies 10 (1993), pp. 79-97.

${ }^{14}$ L'Abbé Martinet, La Philosophie du Catéchisme Catholique (Paris, 1853), p. 284. Unless otherwise stated, all translations in this paper are my own.

${ }^{15}$ Concern over this problem led to the practice, common in medieval and renaissance times, of laying a stone in the valley to reserve one's space on the day of judgement: 'according to Scripture this valley is the location of the Last Judgement, even though it is scarcely a league in length; the Turks, Jews, Arabs and other Levantines who believe this article of faith each put there a stone, as they please (it is said), to reserve their place, awaiting the coming of this great day.' de Vergoncey, Le pèlerin véritable de la Terre Saincte (Paris, 1615), 322.

${ }^{16}$ Aquinas, Summa Theologica, trans. Fathers of the English Dominican Province (New York: Benziger Bros., 1948), V, p. 2926 (q88a4, objection 1).

${ }^{17}$ See, for example, François-Xavier de Feller, Catéchisme philosophique, ou Recueil d'observations propres à défendre la religion chrétienne contre ses ennemis (Paris, 1777, $\left.2^{\text {nd }} \mathrm{edn}\right), \mathrm{p} .558$.

${ }_{18}$ Jacobus de Voragine, The Golden Legend, trans. William Granger Ryan (New Jersey: Princeton University Press, 1993), p. 9.

${ }^{19}$ Jan Ruysbroeck, The Kingdom of the Lovers of God, trans. T. Arnold Hyde (London: Kegan Paul, Trench, Trubner \& Co. Ltd, 1919), p. 192.

${ }^{20}$ Cornelius a Lapide, Commentaria in Omnes Sancti Pauli Epistolas (Turin: Marietti, 1928), p. 386.

${ }^{21}$ Other contemporaries simply rejected the problem outright. For example, the Dutch Remonstrant Phillip van Limborch (1633-1712) wrote: 'it is evident that the particular place of judgement is unknown to us... A single valley is not sufficient to gather together, and reawaken from death, every man who has ever lived in the world.' Philipp van Limborch, Theologia Christiana ad praxin pietatis ac promotionem pacis Christianae unice directa (Amsterdam, 1686), pp. 784-5. And the Swiss divine Jacques Abbadie (1654?-1727) claimed that the problem 'that the valley of Jehoshaphat is too small to contain all men' is one of several 'childish difficulties' that the faithful ought not to concern themselves with, on a par with: 'how can a material fire burn souls?', and 'how can angels sound trumpets when they have no mouths?', since in each case the 'difficulty' arises by taking scripture literally at points on which it is quite obviously not intended to be taken that way. Jacques Abbadie, Traité de la vérité de la religion chrétienne, 2 vols. (Paris, 1684), II, p. 357.

22 Johann Ernst Gerhard, De appellatione ad supremum \& incorruptem Judicem Jesum Christum, quam vulgo Citationem dicunt in Vallem Josaphat, discursus theologicus (Jena, 1664, $2^{\text {nd }}$ edn.), p. 7. 
${ }^{23}$ Jerome, "Epistola 18, ad Damasum papam", in Sanctus Hieronymus. Epistulae, ed. Isidor Hilberg (Vienna, 1910), p. 77.

${ }^{24}$ Gerhard, De appellatione ad supremum \& incorruptem Judicem Jesum Christum, pp. 7-8.

${ }^{25}$ For a list of writers who made this claim prior to the $1660 \mathrm{~s}$, see Gerhard, De appellatione, p. 7.

${ }^{26}$ Edward Pococke, A Commentary on the Prophecy of Joel (Oxford, 1691), p.124.

${ }^{27}$ John Calvin, Commentaries on the Twelve Minor Prophets. Vol. II, Joel, Amos, Obadiah, trans. John Owen (Grand Rapids: Baker Book House Company, 1993), p. 115.

${ }^{28}$ Bénédict Pictet, Theologia Christiana (London: R. Baynes, 1820, $4^{\text {th }}$ edn.), p. 343. Originally published Geneva, 1696.

${ }^{29}$ Peter Dens, Theologia moralis et dogmatica tomus VII (Dublin: Richard Coyne, 1832), pp. 331-2.

${ }^{30}$ For details of Leibniz's use of accommodation and allegory in biblical exegesis, see Daniel J. Cook, 'Leibniz: biblical historian and exegete', in Ingrid Marchlewitz and Albert Heinekamp (eds.), Leibniz' Auseinandersetzung mit Vorgängern und Zeitgenossen (Stuttgart: Franz Steiner, 1990), pp. 270-6.

${ }^{31}$ For Leibniz's references to this work, see his 'Dialogus inter Theologum et Misosophum' in A VI 4, 2218, and New Essays, A VI 6, 521.

${ }^{32}$ A version of this letter is printed in Bernard le Bovier de Fontenelle, Rêveries Diverses, ed. Alain Niderst (Paris: Desjonquères, 1992), pp. 121-3. A different version of it, with numerous minor textual variations, can be found in a manuscript copy held in the Hanover State Library, the Niedersächsische Staatsarchiv, under the shelf mark Dep. 84 A 180, 589-90. To complicate matters, there exist other variants of the letter; for information on these see Robert E. Pike, 'A note on a letter by Fontenelle', Modern Language Notes 52 (1937), pp. 266-7. The copy held in the Hanover State Library is most likely the one Leibniz would have read.

${ }^{33}$ This was one of a number of distinct concerns about whether there would be adequate room for the whole of mankind at and after the time of resurrection. Jewish thinkers of course addressed the cognate problem of how all of God's chosen will be able to fit into the Promised Land after the resurrection. See for example Menasseh Ben Israel, De resurrectione mortuorum Libri Tres (Groningen, 1676, $2^{\text {nd }}$ edn.), pp. 186-7.

${ }^{34}$ I have been unable to identify the 'certain author' Leibniz refers to here.

${ }^{35}$ G. W. Leibniz, Die Werke von Leibniz X, ed. Onno Klopp (Hanover: Klindworth, 1877), pp. 342-3.

${ }^{36}$ But even if Leibniz didn't fuse ideas from the books of Joel and Thessalonians, others certainly did. For instance, the $18^{\text {th }}$-century Baptist theologian John Gill wrote: 'It...is objected by some against an universal resurrection, that the earth will not be sufficient to contain all. This objection may be startling to such who suppose that all men... will be gather'd together into the valley of Jehoshaphat, and be there judged; for if the whole earth cannot contain them, how should that valley? If it could be thought that there is any difficulty in the objection, it might be, in some measure, removed, by observing that whereas the dead in Christ shall rise first, they, with them that shall be found alive, will be caught up together in the clouds, to meet the Lord in the air, and shall be for ever with him; and, it is to be hoped, it may be allowed there will be room enough for them.' John Gill, The Doctrine of the Resurrection Stated and Defended in Two Sermons (London, 1750, $2^{\text {nd }}$ ed.), p. 42 . Here, Gill all but quotes the aforementioned passage from Thessalonians I as part of his solution to the Jehoshaphat problem. ${ }^{37}$ Peter Lombard, Sententiarum libri quattuor, ed. Jacques-Paul Migne (Paris, 1855), 4.48 .4 (cols. 9567).

38 This is a tentative date, advanced by Paul Ritter, compiler of the Ritterkatalog of Leibniz's extant manuscripts.

${ }^{39}$ G. W. Leibniz, unpublished manuscript held in the Gottfried Wilhelm Leibniz Bibliothek Niedersächsische Landesbibliothek, Hanover, under the shelf mark LBr 705, Bl. 119r. I would like to thank the Gottfried Wilhelm Leibniz Bibliothek-Niedersächsische Landesbibliothek for granting me permission to publish my translation of the manuscript.

${ }^{40}$ For example, Marin Mersenne claimed that in the six millennia the world had existed, the number of humans who have ever lived was no greater than 1,932,937,500,000, and perhaps only half that, given that 'wars, plague, and other diseases and accidents make the number of men much less than it would [otherwise] be.' More than a century later, the Jesuit François-Xavier de Feller determined that the number was 200,000,000,000, considerably lower than Mersenne's figure, yet still twenty times higher than Leibniz's. See Marin Mersenne, La vérité des sciences contre les septiques ou Pyrrhoniens (Paris, 1625), p. 808, and Feller, Catéchisme philosophique, p. 558. It is notable that Leibniz, like Mersenne and Feller, assumes that the number of humans who have to be accommodated in the valley of Jehoshaphat is the number of humans who had ever lived up to the time in which he wrote, and no more. Yet neither he nor Mersenne nor Feller, so far as I am aware, believed that the last judgement was imminent, and that the total number of human beings who had ever lived would not experience any 
further increase. It is therefore surprising that when calculating how many people will have to be accommodated at the time of the last judgement, Leibniz (as well as by Mersenne and Feller) takes into account only the number of people who had lived and were alive at the time of writing, with no allowance made for those who would be born in the future, prior to the day of judgement.

${ }^{41}$ Albert Van Helden, Measuring the Universe: Cosmic Dimensions from Aristarchus to Halley (Chicago: University of Chicago Press, 1985), p. 177.

${ }^{42}$ Conrad Bussow, The Disturbed State of the Russian Realm (Montreal: McGill-Queen's University Press, 1994), p. 187.

${ }^{43}$ William W. Hagen, Ordinary Prussians: Brandenburg Junkers and Villagers, 1500-1840

(Cambridge: Cambridge University Press, 2002), p. xiii.

${ }^{44}$ Mersenne, La vérité des sciences, p. 808.

${ }^{45}$ Feller, Catéchisme philosophique, p. 558.

${ }^{46}$ It is noteworthy that Leibniz's two treatments of the problem occur very late in his career, at a time when he is often portrayed as principally interested in rehearsing the doctrines of his mature philosophy in various popular writings.

${ }^{47}$ See A I 5, 26; A I 7, 617; A I 11, 22, cf. A I 9, 487.

48 'I have always thought that Abbé de la Charmoye [i.e. Paul Pezron] was right to think that the chronology of the Chinese (not to mention other arguments) obliges us to extend the antiquity of time... [T] he Septuagint can suffice.' G. W. Leibniz, Die philosophischen schriften von Gottfried Wilhelm Leibniz, ed. C. I. Gerhardt, 7 volumes (Berlin: Weidmann, 1875-90), II, p. 590. For more details on this aspect of Leibniz's thought, see Yuen-Ting Lai, 'Leibniz and Chinese thought', in Allison P. Coudert, Richard H. Popkin and Gordon M. Weiner (eds.), Leibniz, Mysticism and Religion (Dordrecht: Kluwer, 1998), p. 140; Stephan Waldhoff, 'Leibniz und der Plausibilitätsverlust der biblischen

Völkergenealogie', in Daniel J. Cook, Hartmut Rudolph, and Christoph Schulte (eds.), Leibniz und das Judentum (Stuttgart: Franz Steiner, 2008), pp. 173-7. For the popularity of the Septuagint chronology in reconciling Chinese and Biblical history, see David Mungello, Curious Land: Jesuit Accommodation and the Origins of Sinology (Honolulu: University of Hawaii Press, 1989), pp. 42-3, 103, 127.

${ }^{49}$ See G. W. Leibniz, Theodicy, trans. E. M. Huggard (Chicago: Open Court, 1990), pp. 244-5, and Leibniz, Die philosophischen schriften von Gottfried Wilhelm Leibniz, III, pp. 565-6.

${ }^{50}$ See for example A I 18, 390.

${ }^{51}$ See A I 10, 61 .

${ }^{52}$ Saint Augustine, The City of God, trans. Gerald G. Walsh S. J., and Daniel J. Honan (Washington: Catholic University of America Press, 1954) XX.14, pp. 460-1.

${ }^{53}$ Saint Thomas Aquinas, Summa contra gentiles, trans. Charles J. O’ Neil (New York: Image Books, 1957) IV.88.5, p. 329.

${ }^{54}$ A II 1 ( $2^{\text {nd }}$ edition), 184.

${ }^{55}$ John Locke, Mr Locke's reply to the Right Reverend the Lord Bishop of Worcester's Answer to his Second Letter (London, 1699), pp. 176-7.

${ }^{56}$ See A VI 6, 29-34.

${ }^{57}$ Richard H. Popkin, The Third Force in Seventeenth-century Thought (Leiden: Brill, 1992), p. 282. It should be noted that Popkin's question was intended to be rhetorical. 